\title{
On the Development of Intangible Cultural Heritage Souvenir Based on the Perception of Tourists
}

\author{
Haiying Liu, Fuli Han, Jingyi Wang \\ Suihua University, Suihua, China \\ Email: 332671963@qq.com
}

How to cite this paper: Liu, H. Y., Han, F. L., \& Wang, J. Y. (2020). On the Development of Intangible Cultural Heritage Souvenir Based on the Perception of Tourists. Journal of Service Science and Management, 13, 345-356.

https://doi.org/10.4236/jssm.2020.132023

Received: March 23, 2020

Accepted: April 23, 2020

Published: April 26, 2020

Copyright $\odot 2020$ by author(s) and Scientific Research Publishing Inc. This work is licensed under the Creative Commons Attribution International License (CC BY 4.0).

http://creativecommons.org/licenses/by/4.0/

(c) (i) Open Access

\begin{abstract}
The study provided a structural equation model of developing ICH souvenir based on the perception of tourists taking attitude towards protecting $\mathrm{ICH}$, perceived problem, perceived value, customer participation and purchase intention as variables. The research examined the influence of attitude towards protecting ICH, perceived problem, perceived value, customer participation on purchase intention for ICH souvenir. Data were collected by using questionnaires and 396 questionnaires were valid. The data were analyzed through Structural Equation Modeling (SEM) with Amos computer program. The findings showed that attitude towards protecting $\mathrm{ICH}$, perceived value and customer participation had significant and positive influence on purchase intention for ICH souvenir. Perceived value had the most significant and positive influence on purchase intention, followed by customer participation and attitude towards protecting ICH. However, perceived problem had a significant and negative influence on purchase intention for ICH souvenir. At last, some suggestions are given for tourism enterprises to develop ICH souvenir.
\end{abstract}

\section{Keywords}

Intangible Cultural Heritage Souvenir, Attitude towards Protecting ICH, Perceived Problem, Perceived Value, Customer Participation, Purchase Intention

\section{Introduction}

The development of souvenirs is one of ways of Intangible Cultural Heritage (ICH) productive protection. The Chinese government has proposed to strengthen the protection and inheritance of Intangible Cultural Heritage. With the 
promotion of the relevant departments, productive protection has become a trend in the field of Intangible Cultural Heritage protection, which has attracted wide attention from all sectors of society in China. Productive protection for Intangible Cultural Heritage refers to the practice including the production, circulation, sales and other means. During the process, ICH and its resources are made into the cultural products. Tourism development is a way of productive protection of $\mathrm{ICH}$, and souvenir development is an important one of parts.

Zhang and Tian (2016) stated that Intangible Cultural Heritage commodity included collection crafts, such as ceramics, embroidery; the practical life articles, such as willow weaving and bamboo woven articles; the local specialty food, such as a kind of candy; publications, books, audio-visual products; creative products combining traditional handicraft with modern design, such as T-shirt with some elements from an opera. The first three categories are the original tangible products based on the ICH skill. The fourth and fifth categories are subprime derivatives of ICH craft whose market proportion is very small. The commodity usually can be purchased as souvenir in China.

The development of ICH souvenir should be based on the tourist perception. Tourists are the core and the main body of tourism activities, whose psychological demand and travel behavior are important. From the perspective of tourists to study the development of ICH souvenir can establish effective feedback mechanism. This research starts with a review of the literature on the four variables namely attitude towards protecting $\mathrm{ICH}$, perceived problem, perceived value, tourist participation and purchase intention. Then a theoretical model is constructed together with proposed hypotheses. In the framework, the four variables have positive influence on purchase intention. Then, research methods are described, and the model is tested. The analyses of statistical data derived from a survey are presented and discussed. Lastly, based on the analysis results, conclusions and suggestion are drawn.

\section{Literature Review and Hypotheses}

\subsection{Attitude towards Protecting ICH and Purchase Intention}

An attitude is "an enduring organization of motivational, emotional, perceptual and cognitive processes with respect to some aspect of our environment" (Hawkins, Best, \& Coney, 2004). Attitude is an important factor to intention. Meitiana et al. (2019) identified the relationship among attitude, behavior intention by using the Theory of Planned Behavior. They found the attitude towards authenticity and aesthetics had significant influence on the purchase intention. In recent years, the attitude of people to safeguard Intangible Cultural Heritage tends to be positive. Phosikham et al. (2015) put forward tourist perspectives of heritage reservation included intangible heritage such as typical way of life and daily activities, traditional music, classical puppetry, classical dance and so on. They investigated the relationship between tourists attitude to heritage preservation and their satisfaction on tourism. They found tourists who perceived the heritage was preserved well were more satisfied with the tourism activities. Kim \& 
Littrell (2001) stated tourist attitude towards other cultures had influence on purchase intention for souvenir. Ethnocentrism also can affect purchase intention. Tourists with high ethnocentrism did not buy the souvenir from other countries, but purchase their own country's souvenirs. The tourists believed that to purchase the souvenir from their hometown would have a good impact on local economy. So the following hypothesis is formulated:

$\mathrm{H} 1$ : Attitude towards protecting ICH has a significant and positive influence on purchase intention for ICH souvenir.

\subsection{Perceived Problem and Purchase Intention}

Generally speaking, customer perceptions of product problem would affect their willingness to buy. Wang (2017) concluded that if the merchants did not post, customers would think that postage was an additional cost, the price of the product was not equal to the value of the product, the perceived value of the consumer would be relatively low, and customer purchase intention is difficult to achieve. Cheng and Du (2018) stated customer perception of agricultural insurance costs had a negative impact on agricultural insurance satisfaction. This is because the payment is the cost paid by farmers to purchase agricultural insurance. When the cost of agricultural insurance is higher, the perceived value of agricultural insurance by farmers is lower. In the case of a certain premium, the more government premium subsidies, the smaller the burden on farmers, and the higher the satisfaction with agricultural insurance. Thomas and Tsai (2012) regarded psychological distance as an important factor in behavioral decision-making. The problem of the distance of tourist perception of psychological distance affected their perceived value, and then affected their willingness to travel to some destination. Zhang and Tian (2016) stated that excessive commercialization, lack of activities that tourists can participate in, too high product prices and inability to discern the quality of products will indirectly positively affect tourists purchase intentions. So the following hypothesis is formulated:

H2: Perceived problem has a significant and positive influence on purchase intention for ICH souvenir.

\subsection{Perceived Value and Purchase Intention}

Perceived value (PV) is related to value or customer value. Zeithaml (1988) stated perceived value in different ways, one was the value as not high price, the second was the value as what the customer want to get, the third was the value as the quality get from the price the customer pay, and the fourth was the value as what was get for what is given. By customer perceived value, the researchers can study customer purchasing behavior. And these researches had gradually beeb developed in conjunction with consumer psychology. The meaning of customer perceived value is constantly enriched in theory research. Pham et al. (2020) found that perceived value was positively impacted by optimism and innovativeness, and insecurity had negatively effect on perceived value; customer satis- 
faction and purchase intention were positively affected by perceived value. In the meanwhile customer satisfaction had positively influences on purchase intention. Curvelo et al. (2019) stated perceived value affected the purchase intention for organic food. This could increase the likelihood of buying organic foods of customers. In B2C commerce context, Civelek and Ertemel (2019) investigated perceived value had a significant impact on brand loyalty; brand loyalty had a significant influence on purchase intention; perceived value had a direct effect on purchase intention. So the following hypothesis is formulated:

H3: Perceived value has a significant and positive influence on purchase intention for ICH souvenir.

\subsection{Customer Participation and Purchase Intention}

Customer participation is one behavior based on customer' own will and external enterprises. When customers participate in the development of new products of enterprises, they will feel the improvement of their social status, and have a higher sense of self-satisfaction and a stronger willingness to buy (Kantamneni \& Coulson, 1996). Even if the participation behaviors of customers have been terminated, customer intentions to buy productions designed by themselves are strong due to the symbolic value of the products (Elliott, 1997). Cermak et al.'s empirical study (1994) showed that in the service industry, customer participation positively affected customer satisfaction and customer repurchase behavior. Ennew \& Binks (1999) believed that customer participation positively affected customer perceived service quality and satisfaction, indirectly affected customers repurchase behavior, and promoted the improvement of corporate financial performance. The tourist participate in the development of the souvenir is also very important. During the process, through the investigation to understand the demand of tourists, enterprise could gain the reference data to direct production. So the following hypothesis is formulated:

H4: Customer participation has a significant and positive influence on purchase intention for ICH souvenir.

By integrating the research hypotheses in this research, the author constructs a conceptual model of development of Intangible Cultural Heritage souvenir as shown in Figure 1.

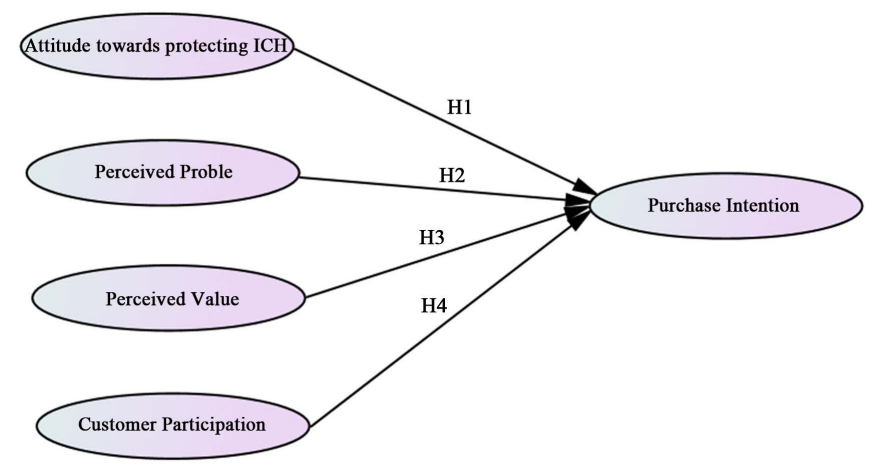

Figure 1. Conceptual model. 


\section{Research Method}

This study adopted quantitative method to prove or disprove these hypotheses, to test the impact of attitude towards protecting $\mathrm{ICH}$, perceived problem, perceived values and customer participation on purchase intention. The data used in this research is the primary data obtained by applying data collection instruments such as questionnaire.

\subsection{Measurement}

Based on the prior related research, the questionnaire was designed. The items in the questionnaire were modified to make them suitable to the $\mathrm{ICH}$ souvenir context. Primary data collection is divided into two parts, the first part is demographics of tourists including gender, age, educational level, occupation, monthly income after tax and other items; the second part is to determine the respondents' perception including attitude towards protecting $\mathrm{ICH}$, perceived problem, customer participation, perceived value and purchase intention. The later part includes 17 items (Table 1). Subsequently, a 5-point Likert-type scale ( $1=$ strongly disagree, $5=$ strongly agree) was used in the questionnaire.

\subsection{Sample}

In this study, the population is the tourists who travelled in Hangzhou City, Zhejiang Province, China where there are ICH souvenirs. More than 5,000,000

Table 1. Measures of construct.

\begin{tabular}{|c|c|c|}
\hline Variables & Measures & Sources \\
\hline $\begin{array}{l}\text { Attitude towards } \\
\text { Protecting ICH } \\
\text { (AT) }\end{array}$ & $\begin{array}{l}\text { Respect the producer of ICH souvenir } \\
\text { Respect the culture of ICH } \\
\text { Safeguarding ICH is valuable }\end{array}$ & $\begin{array}{l}\text { Zhang \& Tian (2016) } \\
\text { Luo et al. (2018) }\end{array}$ \\
\hline $\begin{array}{l}\text { Perceived Problem } \\
\text { (PP) }\end{array}$ & $\begin{array}{l}\text { Cannot identify the quality } \\
\text { High price }\end{array}$ & $\begin{array}{l}\text { Kim \& Littrell (2001) } \\
\text { Zhang \& Tian (2016) }\end{array}$ \\
\hline & $\begin{array}{l}\text { Inconvenient to carry } \\
\text { Educational value }\end{array}$ & \\
\hline $\begin{array}{l}\text { Perceived Value } \\
(\mathrm{PV})\end{array}$ & $\begin{array}{l}\text { Social value } \\
\text { Functional value }\end{array}$ & $\begin{array}{l}\text { Sheth (1991) } \\
\text { Bruce (2014) }\end{array}$ \\
\hline & Relationship Support value & \\
\hline $\begin{array}{l}\text { Customer Participation } \\
\text { (CP) }\end{array}$ & $\begin{array}{l}\text { Paid the physical strength and time } \\
\text { Spent the wisdom } \\
\text { Communicated with artists }\end{array}$ & $\begin{array}{l}\text { Ennew \& Binks (1999) } \\
\text { Huang \& Peng (2017) }\end{array}$ \\
\hline & Be worth buying & \\
\hline $\begin{array}{l}\text { Purchase Intention } \\
\text { (PI) }\end{array}$ & $\begin{array}{l}\text { Intend to purchase } \\
\text { Recommend to others }\end{array}$ & $\begin{array}{l}\text { Dodds (1991) } \\
\text { Liu et al. (2019) }\end{array}$ \\
\hline & Pay for participating ICH activity & \\
\hline
\end{tabular}


tourists one year in this city. Cochran's formula is considered appropriate in situations with large populations. The number of tourist travelled in Hangzhou city is unknown. Since there is a large and unknown population size, the author employed W.G. Cochran sample size formula to calculate the sample in the study. The Cochran formula is:

$$
n_{0}=\frac{Z^{2} p q}{e^{2}}
$$

Based on the above formula, the author calculated the sample:

$$
\mathrm{n}_{0}=\left[(1.96)^{2} *(0.5) *(0.5)\right] /(0.05)^{2}=385
$$

So a sample of 385 tourists in Hangzhou city should be enough to give the confidence levels. To make sure the data more accurate, the author surveyed 500 questionnaires to tourists. These respondents mainly consist of public institution, self-employed, company employee, students and so on. All questionnaires were distributed out and returned back both on the spot. At last, 396 questionnaires were valid.

\subsection{Reliability and Validity Test}

The results of validity and reliability test are displayed in Table 2. Internal consistency is a measure of reliability. One of the most widely used statistical tests is

\begin{tabular}{|c|c|c|c|c|c|}
\hline Variables & Code & KMO & Bartlett's Test (Sig.) & Loading & Cronbach's $\alpha$ \\
\hline \multirow{4}{*}{$\begin{array}{c}\text { Attitude towards } \\
\text { Protecting ICH }\end{array}$} & AT1 & 0.733 & 530.521 & 0.823 & 0.855 \\
\hline & AT2 & & 0.000 & 0.848 & \\
\hline & AT3 & & & 0.819 & \\
\hline & PP1 & 0.715 & 543.571 & 0.868 & 0.854 \\
\hline \multirow[t]{3}{*}{ Perceived Problem } & PP2 & & 0.000 & 0.911 & \\
\hline & PP3 & & & 0.836 & \\
\hline & PV1 & 0.815 & 810.893 & 0.758 & 0.872 \\
\hline \multirow{4}{*}{ Perceived Value } & PV2 & & 0.000 & 0.793 & \\
\hline & PV3 & & & 0.820 & \\
\hline & PV4 & & & 0.774 & \\
\hline & $\mathrm{CP} 1$ & 0.724 & 461.175 & 0.809 & 0.834 \\
\hline \multirow{3}{*}{$\begin{array}{c}\text { Customer } \\
\text { Participation }\end{array}$} & $\mathrm{CP} 2$ & & 0.000 & 0.832 & \\
\hline & $\mathrm{CP} 3$ & & & 0.850 & \\
\hline & PI1 & 0.838 & 863.066 & 0.747 & 0.881 \\
\hline \multirow{3}{*}{ Purchase Intention } & PI2 & & 0.000 & 0.800 & \\
\hline & PI3 & & & 0.808 & \\
\hline & PI4 & & & 0.777 & \\
\hline \multirow{2}{*}{ Total } & & 0.870 & 3791.817 & & 0.848 \\
\hline & & & 0.000 & & \\
\hline
\end{tabular}

Table 2. Reliability and validity analyses. 
Cronbach's alpha. The instrument is said to be reliable if it has Cronbach's alpha $\geq 0.70$. As Table 2 depicted, Cronbach's alpha coefficient of each measurement item, dependent variable and the total scale was all above 0.8 . The closer to 1 , the higher the internal consistency is bias free as well. The reliability evaluation of every dimension is from 0.834 to 0.881 . Thus, it can be emphasized that the reliability of questionnaire of this particular study are satisfied.

All the dimensions and scale items were taken from the related literature which indicates they had basically covered the domain of the research, and were representative. So, content validity had been already satisfied. Construct validity is also assessed through factor loadings. As shown in Table 2, the factor loads are between $0.747-0.911$ which suggested sufficient construct validity. When the scale items correlate positively with the other measurements within the same construct, convergent validity is good. In the meanwhile, the KMO values were all greater than 0.7, and the Bartley sphere test results were less than 0.05. So, the convergent validity of each scale was good.

\section{Findings}

\subsection{Demographic Characteristics of the Sample}

The details of the sample distribution are shown in Table 3. The male and female ratio was $47.0 \%$ to $53.0 \%$, meaning the gender distribution was balanced.

Table 3. Demographic and characteristics of respondents $(\mathrm{N}=396)$.

\begin{tabular}{|c|c|c|c|}
\hline Feature & Category & Num & Percent \\
\hline \multirow{2}{*}{ Gender } & Man & 186 & $47.0 \%$ \\
\hline & Woman & 210 & $53.0 \%$ \\
\hline \multirow{5}{*}{ Age } & Below 12 & 35 & $8.9 \%$ \\
\hline & $13-25$ & 89 & $22.5 \%$ \\
\hline & $26-40$ & 112 & $28.3 \%$ \\
\hline & $41-59$ & 99 & $25.0 \%$ \\
\hline & Above 60 & 61 & $15.3 \%$ \\
\hline \multirow{6}{*}{ Occupation } & Public institution & 81 & $20.5 \%$ \\
\hline & Self-employed & 72 & $18.2 \%$ \\
\hline & Company employee & 87 & $22.0 \%$ \\
\hline & Teacher & 45 & $11.3 \%$ \\
\hline & Student & 63 & $15.9 \%$ \\
\hline & Retired & 48 & $12.1 \%$ \\
\hline \multirow{4}{*}{ Education } & Junior and below & 49 & $12.4 \%$ \\
\hline & High school & 68 & $17.2 \%$ \\
\hline & College & 243 & $61.4 \%$ \\
\hline & Graduate & 36 & $9.0 \%$ \\
\hline \multirow{5}{*}{ Monthly Income } & Below 1999 RMB & 68 & $17.2 \%$ \\
\hline & 2000 - 2999 RMB & 73 & $18.4 \%$ \\
\hline & 3000 - 4999 RMB & 116 & $29.3 \%$ \\
\hline & $5000-6999$ RMB & 113 & $28.5 \%$ \\
\hline & Above 7000 RMB & 26 & $6.6 \%$ \\
\hline
\end{tabular}


In the age structure, tourists between 13 and 25 years old accounted for $22.5 \%$ who paid little attention to ICH souvenir. Tourists under 12 years old (8.9\%) showed great interests in ICH souvenir because of their curiosity. Tourists aged between 26 and $40(28.3 \%)$ were fond of ICH souvenir to build and strengthen relationship and gain knowledge for their children. Regarding education, sample reported that the most degree attained of the respondents was bachelor degree or college degree. The survey finds that because ICH has rich connotation, tourists with a certain level of knowledge appreciated it more. Among the respondents, teachers $(11.3 \%)$ was highly educated and paid more attention to ICH souvenir. These groups fitted well with the characteristics of the mainstream consumer groups in Chinese society and had a good representativeness. In general, the formal sampling survey had statistical validity. The detailed analysis is as follows:

\subsection{Hypothesis Test}

Based on the survey data and the conceptual model, the researcher build a structural model (Figure 2). The structural equation-modeling package of AMOS 24.0 is used to test the model. In particular, for estimation of the fit of the model, the Maximum Likelihood with Bootstrapping of 1000 samples was adopted. A detailed analysis of the results and measures for model fit are in Table 4. The ratio of Chi-square to freedom of the model was 1.937, smaller than the 2 recommended by Bagozzi and Yi (1988) and significant $(p=0.000)$, indicating a very good fit. The score of GFI (a goodness of fit index) is 0.943 , greater than 0.9; the root mean square error of approximation (RMSEA) is 0.049 , less than 0.05. It shows that there is a match between the model and the data. Tucker-Lewis index $(\mathrm{TLI})=0.966$, compare fitting index $(\mathrm{CFI})=0.973$ greater than 0.9 , explain the fit of the model is good and the model is acceptable.

Then, the researchers tested the hypothesized causal relationships among the constructs of the model. Table 5 listed the structural parameter estimates and the hypothesis testing results. The analytical results showed that attitude towards

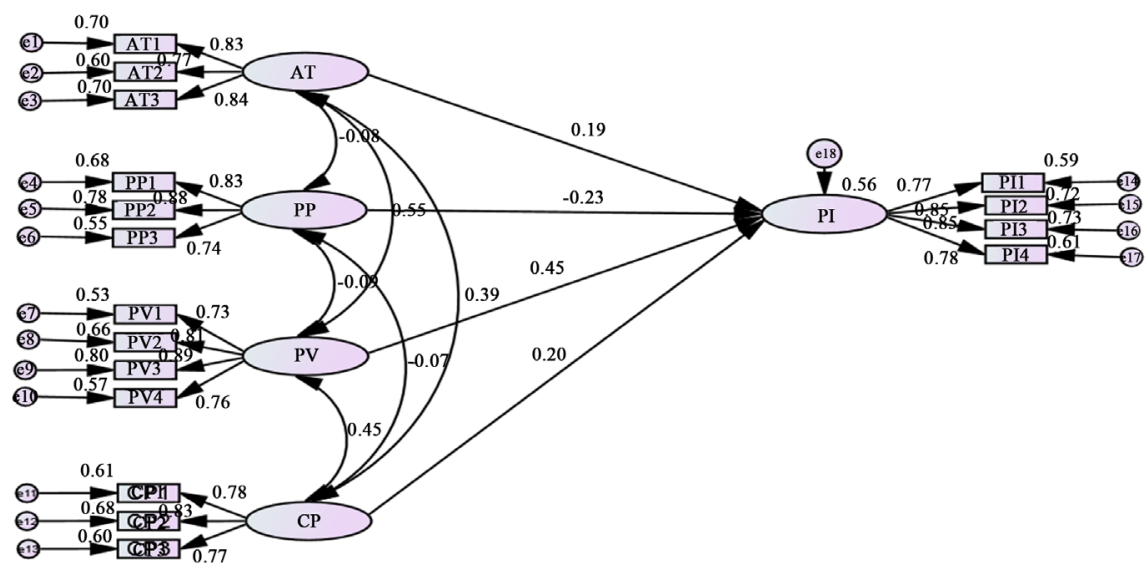

Figure 2. The model of development of intangible cultural heritage souvenir. Note: $\mathrm{AT}=$ Attitude towards protecting ICH, $\mathrm{PP}=$ Perceived Problem, PV = Perceived Value, $\mathrm{CP}=$ Customer Participation, PI = Purchase Intention. 
Table 4. Model fitness test.

\begin{tabular}{ccc}
\hline Fitness Indexes & Value of the tested model & Desired value \\
\hline$\lambda 2 / \mathrm{df}$ & 1.937 & Below 2 \\
PCFI & 0.779 & $0-1$ \\
TLI & 0.966 & Above 0.9 \\
CFI & 0.973 & Above 0.9 \\
GFI & 0.943 & Above 0.9 \\
RMSEA & 0.049 & Below 0.05 \\
\hline
\end{tabular}

Table 5. Results of estimation structural model.

\begin{tabular}{cccccc}
\hline Hypotheses & Estimate & S.E. & C.R. & P & Decision \\
\hline H1: $\mathrm{PI} \leftarrow \mathrm{AT}$ & 0.195 & 0.057 & 3.389 & $* * *$ & Accepted \\
H2: $\mathrm{PI} \leftarrow \mathrm{PP}$ & -0.248 & 0.048 & -5.182 & $* * *$ & Rejected \\
H3: $\mathrm{PI} \leftarrow \mathrm{PV}$ & 0.562 & 0.079 & 7.136 & $* * *$ & Accepted \\
H4: PI $\leftarrow \mathrm{CP}$ & 0.292 & 0.078 & 3.726 & $* * *$ & Accepted \\
\hline
\end{tabular}

Note: ${ }^{* *} P<0.001 ; \mathrm{AT}=$ Attitude towards Protecting ICH, PP = Perceived Problem, PV = Perceived Value, $\mathrm{CP}=$ Customer Participation, PI $=$ Purchase Intention.

protecting ICH has a significant and positive impact on purchase intention (C.R. $=3.389 ; P=0.000)$ (C.R. $>1.96 ; P<0.05$ is significant). So, hypothesis 1 was accepted. Consistent with the hypothesis, tourist perceived value has a significant and positive impact on purchase intention (C.R. $=7.136$; $P=0.000$ ). So, hypothesis 3 was accepted. The hypothesis 4 that customer participate had a significant and positive influence on purchase intention was supported (C.R. $=3.726 ; P$ $=0.000)$. So, hypothesis 4 was accepted. Among them, perceived value has the strongest impact on purchase intention, followed by customer particitation and attitude towards protecting ICH (perceived value: $\beta=0.45$ vs. customer particitation: $\beta=0.20$ vs. attitude towards protecting ICH: $\beta=0.19$ ).

$\mathrm{H} 2$ in this study stated that perceived problem had a significant and positive effect on purchase intention. The result showed that its P-value (0.000) was less than 0.05 , so perceived problem had a significant effect on purchase intention. However, the C.R. $=-5.182$, meaning perceived problem had a negative effect on purchase intention. So, $\mathrm{H} 2$ is rejected.

\section{Conclusion and Recommendation}

\subsection{Conclusion}

Firstly, attitude towards protecting ICH, perceived value and customer participation have significant and positive impacts on purchase intention for the speicial souvenir namely ICH souvenir. This conclusion is consistent with the results mentioned in the previous researches, which verified these factors having effects on purchase intention for souvenir. The study examined the strength of the influence of those factors on purchase intention for ICH souvenir. Perceived value 
had the most significant and positive influence on purchase intention, followed by customer participation and attitude towards protecting $\mathrm{ICH}$.

Secondly, the study stated perceived problem had a significant and negative influence on purchase intention for ICH souvenir. When the tourists found they could not identify the quality of ICH souvenir, the souvenir was expensive, and it was inconvenient to carry the souvenir, they had no intention to purchase. The less problem the tourist felt, the stronger willingness they had to buy ICH souvenir.

\subsection{Implication}

The research can expand the perspective of academic research in the field of cultural heritage. Previous studies usually concentrated on the cultural heritage and tangible cultural heritage, but intangible cultural heritage is rarely significantly stated. The study focuses on not ICH tourism, but ICH souvenir. The findings will broaden the traditional research framework on intangible cultural heritage and will offer new research opportunities for future studies.

The research can also expand the perspective of academic research in souvenir. The academic circles mainly focus on the development and design of souvenirs, and rarely study souvenirs from the perspective of tourist in China. This study attempts to study souvenirs from the perspective of tourist willingness to purchase.

\subsection{Recommendation}

Firstly, to propagate ICH protection, the government agencies and tourism enterprises can promote protecting ICH by expressing to tourists that buying ICH souvenir can protect ICH. In China, publicity efforts by government departments are greater than tourism companies. This study demonstrated tourists' attitude towards protecting ICH had significant positive influence on purchase intention. When the tourists have the positive attitude towards protecting $\mathrm{ICH}$, they could buy ICH souvenir. Altogether, after government agencies and tourism enterprises propagate the significance of the protection and development of $\mathrm{ICH}$, tourist purchase intention will also be improved.

Secondly, to understand the diverse needs of tourists, tourism companies should do market research before developing ICH souvenir. When the tourists can identify the quality of ICH souvenir, they would like to buy them. When ICH souvenirs are cheap with high quality and it is convenient to carry them, the tourists could have the high intention to purchase. When the tourists thought that ICH souvenir could bring more perceived value, they would buy them. The perceived value includes the tourist felt ICH souvenir could be used in daily days, could bring knowledge to them, improve their social image and strengthen or build their relationship. To give more perceive value to tourists, the tourism enterprises could success.

Thirdly, to promote tourists to participate the activities about ICH. If the tourists pay the physical strength and wisdom, spend their time, communicate 
with ICH artists and heirs, they would prefer ICH and ICH souvenir. So, tourism enterprises can attract tourists to participate in the performance of Intangible Cultural Heritage and make them feel the charm of Intangible Cultural Heritage. Interact and communicate with inheritors of ICH can expand tourist knowledge of $\mathrm{ICH}$. In the process of participation, tourists may put forward ideas on functions and designs which is beneficial for tourism enterprises to find defects in souvenirs and improve product functions.

\subsection{Limitations and Future Research}

This paper has some limitations and future research direction. First, this paper explored the effect of attitude towards protecting ICH, perceived problem, customer participation, customer perceived value on purchase intention for ICH souvenirs, but failed to fully propose and verify other influence factors. In the future, antecedent variables such as cultural identity can be added. Second, this paper used quantitative analysis method to study the development of ICH souvenir. In the future, it is necessary to dimensionally subdivide customer perceived value of ICH souvenir based on the qualitative methods.

\section{Acknowledgements}

This paper is from Project of Philosophy and Social Science Research of Heilongjiang Province of China (Grant No. 17YSE395); Project of Art and Science of Heilongjiang Province of China (Grant No. 2016D109); Key Project of Suihua University of Heilongjiang Province of China (Grant No. H201701002). Fundamental Research Funds of Department of Education Heilongjiang Province of China (Grant No. KYYWF10236180221).

\section{Conflicts of Interest}

The authors declare no conflicts of interest regarding the publication of this paper.

\section{References}

Cermak, D. S. P., File, K. M., \& Prince, R. A. (1994). Customer Participation in Service Specification and Delivery. Journal of Applied Business Research, 10, 90-98. https://doi.org/10.19030/jabr.v10i2.5942

Cheng, J., \& Du, Z. (2018). Research on Satisfaction of Farmers' Policy Agricultural Insurance Based on Perceived Value. Financial Theory and Practice, 7, 58-64.

Civelek, M. E., \& Ertemel, A. V. (2019). The Role of Brand Equity and Perceived Value for Stimulating Purchase Intention in B2C e-Commerce Web Sites. Business and Economics Research Journal, 10, 233-243. https://doi.org/10.20409/berj.2019.165

Curvelo, I., Watanabe, E., \& Alfinito, S. (2019). Purchase Intention of Organic Food under the Influence of Attributes, Consumer Trust and Perceived Value. Revista de Gestão, 26, 198-211. https://doi.org/10.1108/REGE-01-2018-0010

Elliott, R. (1997). Existential Consumption and Irrational Desire. European Journal of Marketing, 31, 285-296. https://doi.org/10.1108/03090569710162371 
Ennew, C. T., \& Binks, M. R. (1999). Impact of Participative Service Relationships on Quality, Satisfaction and Retention: An Exploratory Study. Journal of Business Research, 46, 121-132. https://doi.org/10.1016/S0148-2963(98)00016-2

Hawkins, D. I., Best, R. J., \& Coney, K. A. (2004). Consumer Behaviour: Building Market Strategy (9th Edition). McGraw-Hill/Irwin.

Kantamneni, S., \& Coulson, K. (1996). Measuring Perceived Alue: Scale Development and Research Findings from a Consumer Survey. Journal of Marketing Management, 6, 72-86.

Kim, S., \& Littrell, M. A. (2001). Souvenir Purchase Intention for Self versus Others. Annals of Tourism Research, 28, 638-657. https://doi.org/10.1016/S0160-7383(00)00064-5

Meitiana, M., Setiawan, M., Rohman, F., \& Irawanto, D. W. (2019). Factors Affecting Souvenir Purchase Behavior: Valuable Insight for Tourism Marketers and Industry. Journal of Business and Retail Management Research, 13, 248-255. https://doi.org/10.24052/JBRMR/V13IS03/ART-22

Pham, L., Williamson, S., Lane, P., Limbu, Y., Nguyen, P. T. H., \& Coomer, T. (2020). Technology Readiness and Purchase Intention: Role of Perceived Value and Online Satisfaction in the Context of Luxury Hotels. Management and Decision Making, 19, 91-117. https://doi.org/10.1504/IJMDM.2020.104208

Phosikham, T., Vilayphone, A., Wayakone, S., \& Phimmavong, S. (2015). Tourists' Attitudes towards Tourism Development and Heritage Preservation in the World Heritage Town of Luang Prabang, Lao PDR. International Journal of Business and Social Science, 8, 37-48.

Rokeach, M., \& Kliejunas, P. (1972). Behavior as a Function of Attitude-toward-Object and Attitude-toward-Situation. Journal of Personality and Social Psychology, 22, 194-201. https://doi.org/10.1037/h0032614

Thomas, M., \& Tsai, C. I. (2012). Psychological Distance and Subjective Experience: How Distancing Reduces the Feeling of Difficulty. Journal of Consumer Research, 39, 324-340. https://doi.org/10.1086/663772

Wang, X. Z. (2017). The Influence of Online Shopping Price Framework on Consumers' Perceived Value and Purchase Willingness. Consumer Market, 14, 36-39.

Zeithaml, V. A. (1988). Consumer Perceptions of Price, Quality and Value: A Means-End Model and Synthesis of Evidence. Journal of Marketing, 52, 2-22. https://doi.org/10.1177/002224298805200302

Zhang, X. Y., \& Tian, C. (2016). Influence Mechanism of Tourism Development on Intangible Cultural Heritages (ICH) Based on the Perception of Tourists: A Case Study of Traditional Handicraft Suzhou Embroidery. Geographical Research, 35, 590-604. 